\title{
Cu-Click Compatible Triazabutadienes to Expand the Scope of Aryl Diazonium Ion Chemistry
}

\author{
Brandon M. Cornali, Flora W. Kimani, John C. Jewett* \\ Department of Chemistry and Biochemistry, University of Arizona, 1306 E. University Blvd, \\ Tucson, AZ, 85721 \\ Email. jjewett@email.arizona.edu
}

\section{Supporting Information}

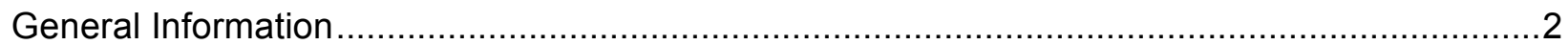

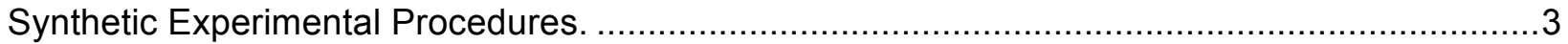

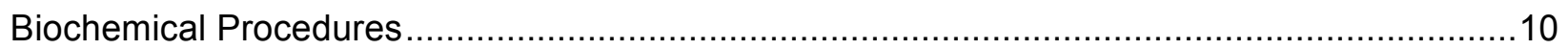

Absorbance and Emission of Triazabutadiene 5d in Aqueous Environment .........................12

Absorbance and Emission of Triazabutadiene 5d in Dimethyl Sulfoxide .............................13

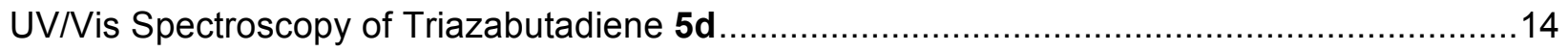

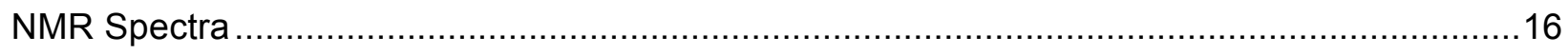

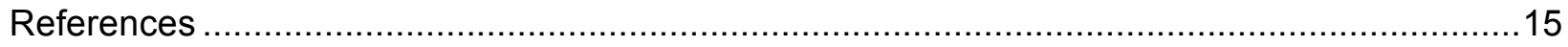




\section{Experimental Procedures and Characterization}

\section{General Information}

All reactions were performed under an argon atmosphere, with the flasks oven dried and cooled in a vacuum oven prior to use. 4-aminobenzoic acid, copper (I) iodide, 1-Ethyl-3-(3dimethylaminopropyl)carbodiimide hydrochloride, hexyl bromide, hydroxybenzotriazole, 1,1,4,7,7-pentamethyldiethylenetriamine, potassium tert-butoxide, propargyl amine, resorcinol, sodium azide, sodium hydride, sodium iodide, sodium nitrite, thionyl chloride, triethylamine, and the below utilized solvents were commercially obtained and used as received. Spectroscopic characterization was done on Bruker Avance-III $400 \mathrm{MHz}$ and Bruker DRX-500 for ${ }^{1} \mathrm{H}$ and ${ }^{13} \mathrm{C}$ NMR and referenced with residual solvent peaks, $\mathrm{CDCl}_{3} 7.26 \mathrm{ppm}$ and $77.0 \mathrm{ppm},\left(\mathrm{CD}_{3}\right)_{2} \mathrm{SO} 2.5$ $\mathrm{ppm}$ and $39.52 \mathrm{ppm}$. Coupling on the spectra is expressed in hertz and abbreviations for multiplicities given as $s=$ singlet, $d=$ doublet, $t=$ triplet, $d d=$ doublet of doublets, $t d=$ triplet of doublets, and $\mathrm{m}=$ multiplet where applicable. Mass spectral analysis was performed on a Bruker ICR-ESI. Fluorescent imaging data characterization was on a Pharos FX Plux Molecular Imager. Centrifugation of samples was done on a Eppendorf Centrifuge $5415 \mathrm{C}$. UV/Vis studies were performed on a Agilent 8453 UV-visible Spectrophotometer. Emission/Excitation was performed on a QuantaMaster 400 Steady State Spectrofluorometer. 


\section{Synthetic Experimental Procedures}

4-azidobenzoic acid (SI-1)

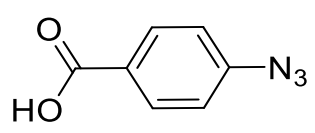

The azide was synthesized according to literature procedure ${ }^{1}$ substituting the starting amine with 4-aminobenzoic acid. To a suspension of 4-aminobenzoic acid $(0.50 \mathrm{~g}, 3.7 \mathrm{mmol}, 1.0$ equiv.) in water $(2.5 \mathrm{~mL})$, concentrated hydrochloric acid $(0.90 \mathrm{~mL})$ was added and the mixture cooled to $-5^{\circ} \mathrm{C}$. A solution of sodium nitrite $(0.26 \mathrm{~g}, 3.8 \mathrm{mmol}, 1.0$ equiv.) dissolved in water $(7.5$ $\mathrm{mL}$ ) was added dropwise while stirring. The resulting solution was stirred for $30 \mathrm{~min}$ at $5^{\circ} \mathrm{C}$. The reaction mixture was poured into a solution of sodium azide $(0.27 \mathrm{mg}, 4.1 \mathrm{mmol}, 1.1$ equiv.) dissolved in water $(7.5 \mathrm{~mL})$ and ice $(5.0 \mathrm{~g})$. A pale yellow precipitate formed immediately. The reaction mixture was left to sit overnight. The precipitate was isolated by filtration, washed with water and air dried to give the product $(0.50 \mathrm{~g}, 84 \%) .{ }^{1} \mathrm{H} \mathrm{NMR}\left(500 \mathrm{MHz},\left(\mathrm{CD}_{3}\right)_{2} \mathrm{SO}\right) \delta 8.11-$ $7.77(\mathrm{~m}, 2 \mathrm{H}), 7.41-7.02(\mathrm{~m}, 2 \mathrm{H}) .{ }^{13} \mathrm{C} N \mathrm{NMR}\left(125 \mathrm{MHz},\left(\mathrm{CD}_{3}\right)_{2} \mathrm{SO}\right) \delta 167.0,144.4,131.7,127.8$, 119.7 .

Methyl 4-azidobenzoate (2)<smiles>COC(=O)c1ccc(N)cc1</smiles>

To a solution of 4-azidobenzoic acid $(0.30 \mathrm{~g}, 1.8 \mathrm{mmol}, 1.0$ equiv.) in $10 \mathrm{~mL}$ methanol was cooled to $0{ }^{\circ} \mathrm{C}$. To this solution, thionyl chloride $(0.30 \mathrm{~mL}, 4.1 \mathrm{mmol}, 2.3$ equiv.) was added dropwise. The reaction mixture was allowed to warm up to room temperature and stirred overnight. The solvent was removed and the residue purified by a flash chromatography using ethyl acetate: hexane $(0.5: 9.5)$ to give the product as a yellow oil that solidifies upon standing $(0.31 \mathrm{~g}, 94 \%) .{ }^{1} \mathrm{H}$ NMR $\left(500 \mathrm{MHz} \mathrm{CDCl}_{3}\right) \delta 8.05-8.00(\mathrm{~m}, 2 \mathrm{H}), 7.08-7.05(\mathrm{~m}, 2 \mathrm{H}), 3.91(\mathrm{~s}$, $3 \mathrm{H}) .{ }^{13} \mathrm{C}$ NMR $\left(125 \mathrm{MHz}, \mathrm{CDCl}_{3}\right) \delta 166.4,144.9,131.5,126.8,119.0,52.3$.

\section{Methyl (E)-4-((1, 3-dimesityl-1, 3-dihydro-2H-imidazol-2-ylidene) triaz-1-en-1-yl) benzoate} (4)

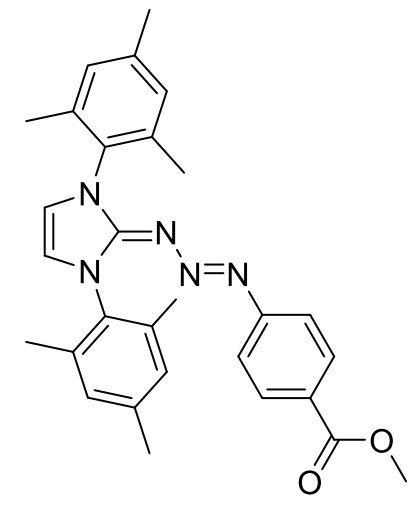


The compound was synthesized based on a literature procedure by Bugarin and co-workers ${ }^{2}$ with a modification of the starting salt. To a stirred suspension of 1, 3-dimesityllimidazolium chloride $^{3}$ (3) $(0.20 \mathrm{~g}, 0.59 \mathrm{mmol}, 1.0$ equiv.) in dry THF (5 mL) was added methyl 4azidobenzoate (2) $(0.10 \mathrm{~g}, 0.59 \mathrm{mmol}, 1.0$ equiv.) in one portion and the reaction mixture was allowed to stir at room temperature for 5 minutes. $\mathrm{NaH}(0.025 \mathrm{~g}, 0.62 \mathrm{mmol}, 60 \%$ in mineral oil, 1.1 equiv.) was added in one portion and stirring was continued at room temperature for further $16 \mathrm{hrs}$. Hexanes $(1.0 \mathrm{~mL})$ were then added and the reaction mixture was filtered through celite. After removal of the solvent under reduced pressure the crude product was washed with hexanes to yield the product as a yellow powder $(0.21 \mathrm{~g}, 74 \%) .{ }^{1} \mathrm{H}$ NMR $\left(500 \mathrm{MHz}, \mathrm{CDCl}_{3}\right) \delta$ $7.71-7.67(\mathrm{~m}, 2 \mathrm{H}), 7.00(\mathrm{dd}, J=1.4,0.7 \mathrm{~Hz}, 4 \mathrm{H}), 6.63(\mathrm{~s}, 2 \mathrm{H}), 6.59-6.56(\mathrm{~m}, 2 \mathrm{H}), 3.86(\mathrm{~s}$, $3 \mathrm{H}), 2.38(\mathrm{~s}, 6 \mathrm{H}), 2.16(\mathrm{~s}, \mathrm{~J}=0.6 \mathrm{~Hz}, 12 \mathrm{H}) .{ }^{13} \mathrm{C}$ NMR $\left(125 \mathrm{MHz}, \mathrm{CDCl}_{3}\right) \delta 167.3,155.3,151.6$, 138.9, 134.92, 133.9, 129.8, 129.4, 126.3, 120.9, 117.3, 51.8, 21.1, 18.0. HRMS calculated for $\mathrm{C}_{29} \mathrm{H}_{31} \mathrm{~N}_{5} \mathrm{O}_{2}[\mathrm{M}+\mathrm{H}]+482.2550$, measured 482.2556

\section{(E)-4-((1,3-dimesityl-1,3-dihydro-2H-imidazol-2-ylidene)triaz-1-en-1-yl)-N-(prop-2-yn-1-} yl)benzamide (1)

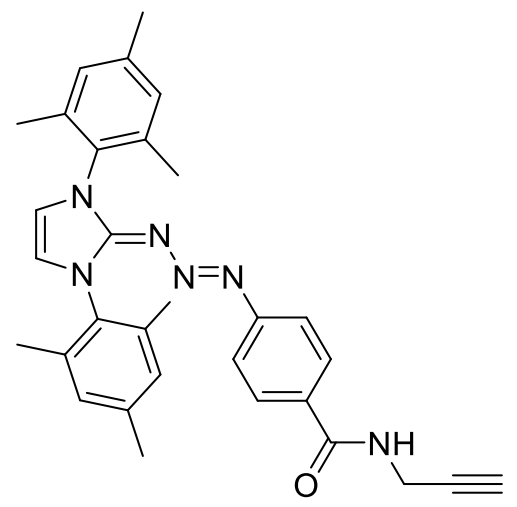

Compound 1 was synthesized according to a modified literature procedure. ${ }^{4}$ To a solution of the methyl ester compound (4) $(0.050 \mathrm{~g}, 0.10 \mathrm{mmol}, 1.0$ equiv.) in $5.0 \mathrm{~mL}$ methanolic potassium hydroxide. This mixture was heated to reflux and upon conversion to the potassium salt ( $5 \mathrm{hr}$., reaction followed by TLC), the solvent was removed by rotavap to complete dryness. The residue was washed with ethyl ether and decanted. The left over residue was picked up in dichloromethane and filtered (Eastman filter paper) to get rid of excess $\mathrm{KOH}$. The dichloromethane was transferred to a round bottom flask and concentrated down and put under argon. The residue was dissolved in $5 \mathrm{~mL}$ of dichloromethane. Propargyl amine $(0.02 \mathrm{~mL}, 0.23$ mmol, 2.3 equiv.), EDCl-HCl (0.03 g, $0.16 \mathrm{mmol}, 1.5$ equiv.), HOBt (0.03 g, $0.19 \mathrm{mmol}, 1.8$ equiv.) and triethylamine ( $0.03 \mathrm{~mL}, 0.22 \mathrm{mmol}, 2$ equiv.) were added and the reaction stirred for $48 \mathrm{hrs}$. at room temp. The reaction was quenched with brine and extracted with dichloromethane $(2 \times 15 \mathrm{~mL})$ and dried over $\mathrm{Na}_{2} \mathrm{SO}_{4}$. The solvent was removed under pressure and the resulting residue was purified by flash column chromatography using ethyl acetate: hexane $(7: 3)$ to yield 1 as an orange solid $(0.038 \mathrm{~g}, 73 \%)$. ${ }^{1} \mathrm{H}$ NMR $\left(400 \mathrm{MHz}, \mathrm{CDCl}_{3}\right) \delta 7.46-$ $7.42(\mathrm{~m}, 2 \mathrm{H}), 6.99(\mathrm{~s}, 4 \mathrm{H}), 6.62(\mathrm{~s}, 2 \mathrm{H}), 6.61-6.56(\mathrm{~m}, 2 \mathrm{H}), 4.21(\mathrm{dd}, \mathrm{J}=5.2,2.6 \mathrm{~Hz}, 2 \mathrm{H}), 2.37$ $(\mathrm{s}, 6 \mathrm{H}), 2.26(\mathrm{t}, \mathrm{J}=2.6 \mathrm{~Hz}, 1 \mathrm{H}), 2.16(\mathrm{~s}, 12 \mathrm{H}) .{ }^{13} \mathrm{C}$ NMR $\left(100 \mathrm{MHz}, \mathrm{CDCl}_{3}\right) \delta$ 167.2, 154.5, $151.7,139.0,135.0,134.0,130.0,129.5,127.3,121.2,117.3,79.9,71.7,29.8,21.2,18.0$. HRMS calculated for $\mathrm{C}_{31} \mathrm{H}_{32} \mathrm{~N}_{6} \mathrm{O}[\mathrm{M}+\mathrm{H}]+505.2710$, measured 505.2712 
(E)-4-((1,3-dimesityl-1,3-dihydro-2H-imidazol-2-ylidene)triaz-1-en-1-yl)-N-((1-(4methoxyphenyl)-1H-1,2,3-triazol-4-yl)methyl)benzamide (5a)

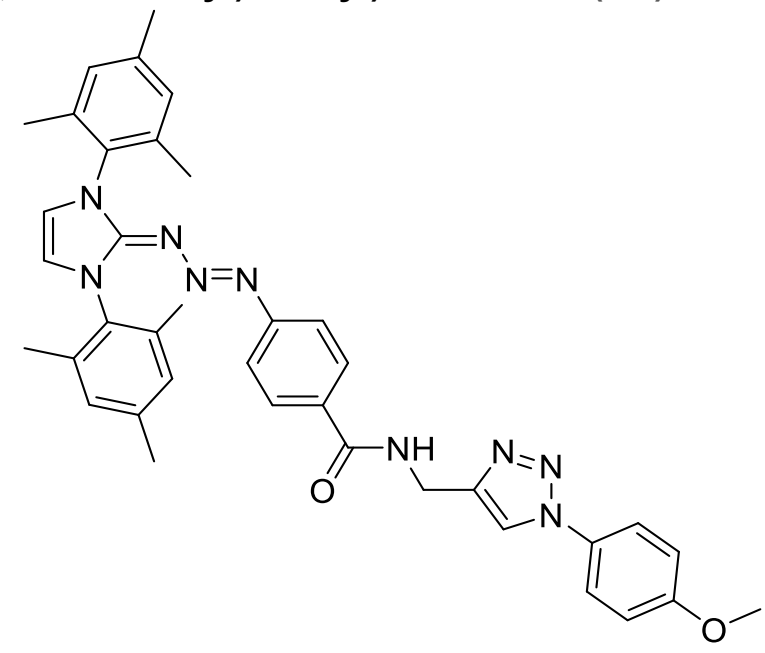

Compound $\mathbf{5 a}$ was synthesized according to a modified literature procedure. ${ }^{5} \mathrm{~A}$ THF solution of $0.20 \mathrm{M}$ of (E)-4-((1,3-dimesityl-1,3-dihydro-2H-imidazol-2-ylidene)triaz-1-en-1-yl)-N-(prop-2-yn1-yl)benzamide (1) $(0.060 \mathrm{~g}, 0.12 \mathrm{mmol}, 10$ equiv.) was added at room temperature, under Argon, to a stirred suspension of 1-azido-4-methoxy benzene ${ }^{6}$ in THF $(0.24 \mathrm{~mL}, 1.0 \mathrm{M}, 0.24$ mmol, 2.0 equiv.) and Cul $(0.023 \mathrm{~g}, 0.12 \mathrm{mmol}, 1.0$ equiv.), then 1,1,4,7,7pentamethyldiethylenetriamine $(0.050 \mathrm{~mL}, 0.24 \mathrm{mmol}, 2.0$ equiv. $)$. The mixture was stirred at room temperature for 4 hrs., and then the reaction was quenched with sat. $\mathrm{NH}_{4} \mathrm{Cl}(5.0 \mathrm{~mL})$ and extracted with ethyl acetate $(3 \times 15 \mathrm{~mL})$. The combined organic extracts were washed with $\mathrm{H}_{2} \mathrm{O}$ $(3 \times 20 \mathrm{~mL})$, dried $\left(\mathrm{Na}_{2} \mathrm{SO}_{4}\right)$, and concentrated under vacuum. The residue was purified by flash column chromatography using methanol: dichloromethane (1:99) as eluent to provide yellow crystals (5a) $(0.039 \mathrm{~g}, 50 \%) .{ }^{1} \mathrm{H}$ NMR $\left(400 \mathrm{MHz}, \mathrm{CDCl}_{3}\right) \delta 7.96(\mathrm{~s}, 1 \mathrm{H}), 7.62-7.56(\mathrm{~m}, 2 \mathrm{H})$, $7.50-7.45(\mathrm{~m}, 2 \mathrm{H}), 7.01-6.96(\mathrm{~m}, 6 \mathrm{H}), 6.61(\mathrm{~d}, \mathrm{~J}=1.0 \mathrm{~Hz}, 2 \mathrm{H}), 6.57(\mathrm{~m}, 2 \mathrm{H}), 4.76-4.71(\mathrm{~s}$, $2 \mathrm{H}), 3.86-3.84(\mathrm{~d}, 3 \mathrm{H}), 2.36(\mathrm{~s}, 6 \mathrm{H}), 2.14(\mathrm{~s}, 12 \mathrm{H}) .{ }^{13} \mathrm{C} \mathrm{NMR}\left(100 \mathrm{MHz}, \mathrm{CDCl}_{3}\right) \delta$ 167.6, 159.9, $154.4,151.7,145.7,139.0,135.0,134.0,130.6,130.2,129.5,127.3,122.3,121.2,121.1,117.3$, 114.9, 55.7, 35.5, 21.3, 18.0. HRMS calculated for $\mathrm{C}_{38} \mathrm{H}_{39} \mathrm{~N}_{9} \mathrm{O}_{2}[\mathrm{M}+\mathrm{H}]+654.3300$, measured 654.3301 
(E)-4-((1,3-dimesityl-1,3-dihydro-2H-imidazol-2-ylidene)triaz-1-en-1-yl)-N-((1-(4(trifluoromethyl)phenyl)-1H-1,2,3-triazol-4-yl)methyl)benzamide (5b)

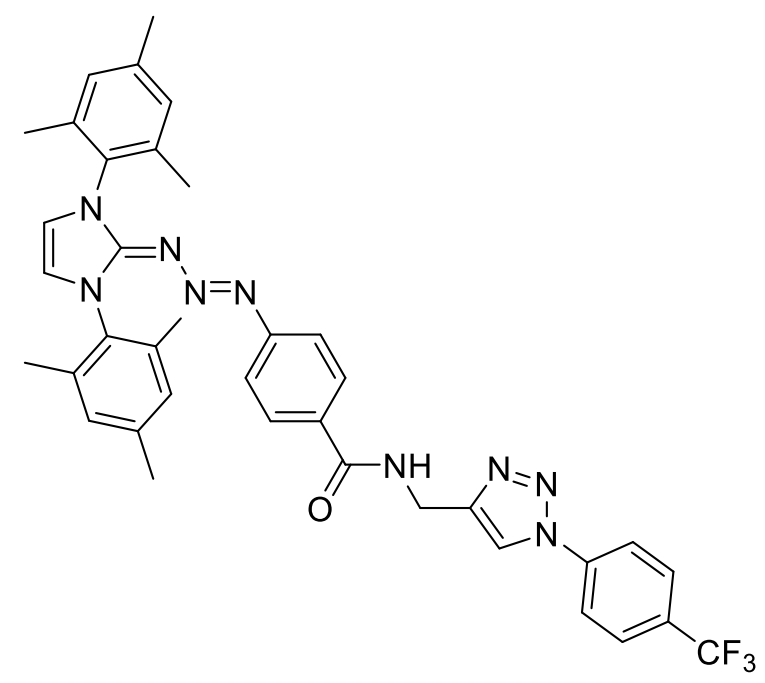

Compound $\mathbf{5 b}$ was synthesized according to a modified literature procedure. ${ }^{5} \mathrm{~A}$ THF solution of $0.15 \mathrm{M}$ of (E)-4-((1,3-dimesityl-1,3-dihydro-2H-imidazol-2-ylidene)triaz-1-en-1-yl)-N-(prop-2-yn1-yl)benzamide (1) $(0.045 \mathrm{~g}, 0.089 \mathrm{mmol}, 1.0$ equiv.) was added at room temperature, under Argon, to a stirred suspension of 1-azido-4-(trifluoromethyl)benzene ${ }^{6}$ in THF $(0.18 \mathrm{~mL}, 1 \mathrm{M}, 0.18$ mmol, 2.0 equiv.) and Cul $(0.020 \mathrm{~g}, 0.11 \mathrm{mmol}, 1.2$ equiv. $)$, then 1,1,4,7,7pentamethyldiethylenetriamine $(0.040 \mathrm{~mL}, 0.18 \mathrm{mmol}, 2.0$ equiv. $)$. The mixture was stirred at room temperature overnight, and then the reaction was quenched with sat. $\mathrm{NH}_{4} \mathrm{Cl}(5.0 \mathrm{~mL})$ and extracted with ethyl acetate $(3 \times 15 \mathrm{~mL})$. The combined organic extracts were washed with $\mathrm{H}_{2} \mathrm{O}$ $(3 \times 20 \mathrm{~mL})$, dried $\left(\mathrm{Na}_{2} \mathrm{SO}_{4}\right)$, and concentrated under vacuum. The residue was purified by flash column chromatography using ethyl acetate: hexane $(7.5: 2.5)$ as eluent to provide yellow crystals (5b) $(0.042 \mathrm{~g}, 68 \%)$. ${ }^{1} \mathrm{H}$ NMR $\left(400 \mathrm{MHz}, \mathrm{CDCl}_{3}\right) \delta 8.15(\mathrm{~s}, 1 \mathrm{H}), 7.87(\mathrm{~d}, \mathrm{~J}=8.3 \mathrm{~Hz}, 2 \mathrm{H})$, $7.76(\mathrm{~d}, J=8.2 \mathrm{~Hz}, 2 \mathrm{H}), 7.47(\mathrm{~d}, J=8.3 \mathrm{~Hz}, 2 \mathrm{H}), 6.97(\mathrm{~s}, 4 \mathrm{H}), 6.61(\mathrm{~s}, 2 \mathrm{H}), 6.55(\mathrm{dd}, J=8.6$, $2.1 \mathrm{~Hz}, 2 \mathrm{H}), 4.74(\mathrm{~d}, J=5.9 \mathrm{~Hz}, 2 \mathrm{H}), 2.35(\mathrm{~s}, 6 \mathrm{H}), 2.13(\mathrm{~s}, 12 \mathrm{H}) .{ }^{13} \mathrm{C} \mathrm{NMR}\left(100 \mathrm{MHz}, \mathrm{CDCl}_{3}\right) \delta$ 167.6, 151.4, 146.6, 139.5, 139.1, 135.0, 133.8, 130.5, 130.4, 130.1, 129.5, 127.4, 127.1, 122.3, $121.0,120.5,117.4,116.9,35.4,21.2,18.0$. HRMS calculated for $\mathrm{C}_{38} \mathrm{H}_{36} \mathrm{~F}_{3} \mathrm{~N}_{9} \mathrm{O}[\mathrm{M}+\mathrm{H}]+$ 692.3068, measured 692.3078

Hexyl azide (SI-2)

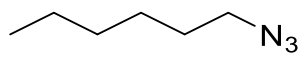

A flask was loaded with of hexyl bromide $(0.50 \mathrm{~mL}, 3.6 \mathrm{mmol}, 1.0$ equiv. $)$, in $5 \mathrm{~mL}$ of DMF. Sodium iodide $(0.53 \mathrm{~g}, 3.6 \mathrm{mmol}, 1.0$ equiv.) and sodium azide ( $0.46 \mathrm{~g}, 7.1 \mathrm{mmol}, 2.0$ equiv.) were subsequently added. The reaction vessel was allowed to stir at $50{ }^{\circ} \mathrm{C}$ for $48 \mathrm{hrs}$. The reaction mixture was allowed to cool, and was poured into $\sim 20 \mathrm{~mL}$ of saturated lithium chloride solution, the aqueous solution was extracted once with $40 \mathrm{~mL}$ of ethyl ether, the organic layer was separated and washed once with brine. The organic layer was dried with $\mathrm{MgSO}_{4}$, and concentrated under reduced pressure to yield $0.32 \mathrm{~g}$ of SI-2 $(71 \%)$. ${ }^{1} \mathrm{H} \mathrm{NMR}\left(400 \mathrm{MHz}, \mathrm{CDCl}_{3}\right)$ $\delta 3.26(\mathrm{t}, J=7.0 \mathrm{~Hz}, 2 \mathrm{H}), 1.67-1.54(\mathrm{~m}, 2 \mathrm{H}), 1.45-1.25(\mathrm{~m}, 6 \mathrm{H}), 0.94-0.87(\mathrm{~m}, 3 \mathrm{H}) .{ }^{13} \mathrm{C}$ NMR $\left(100 \mathrm{MHz}, \mathrm{CDCl}_{3}\right) \delta 51.5,31.3,28.8,26.4,22.5,14.0$ 
(E)-4-((1,3-dimesityl-1,3-dihydro-2H-imidazol-2-ylidene)triaz-1-en-1-yl)-N-((1-hexyl-1H1,2,3-triazol-4-yl)methyl)benzamide (5c)

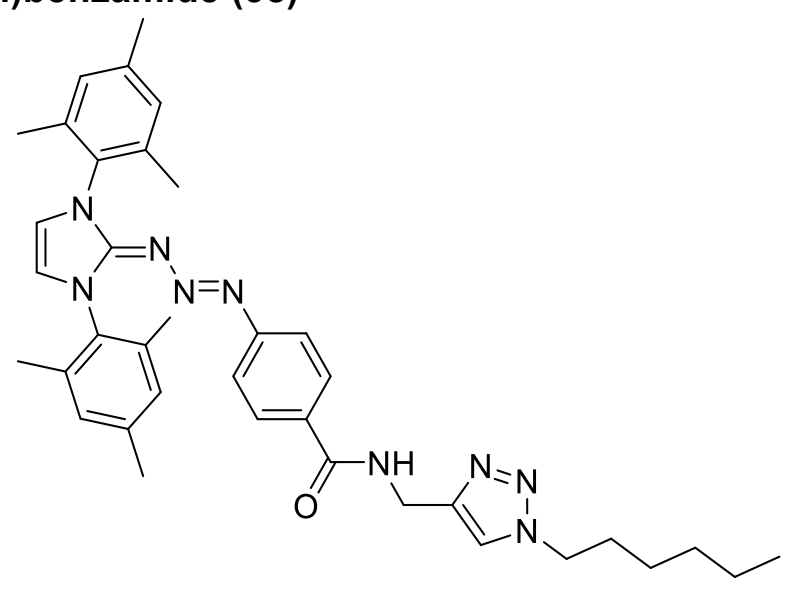

Compound $\mathbf{5 c}$ was synthesized according to a modified literature procedure. ${ }^{5} \mathrm{~A}$ THF solution of $0.20 \mathrm{M}$ of (E)-4-((1,3-dimesityl-1,3-dihydro-2H-imidazol-2-ylidene)triaz-1-en-1-yl)-N-(prop-2-yn1-yl)benzamide (1) $(0.060 \mathrm{~g}, 0.12 \mathrm{mmol}, 1.0$ equiv.) was added at room temperature, under Argon, to a stirred suspension of 1-azidohexane SI-2 in THF $(0.38 \mathrm{~mL}, 0.63 \mathrm{M}, 0.24 \mathrm{mmol}, 2.0$ equiv.) and $\mathrm{Cul}(0.023 \mathrm{~g}, 0.12 \mathrm{mmol}, 1.0$ equiv.), then 1,1,4,7,7-pentamethyldiethylenetriamine $(0.050 \mathrm{~mL}, 0.24 \mathrm{mmol}, 2.0$ equiv.). The mixture was stirred at room temperature for $6 \mathrm{hrs}$. and then the reaction was quenched with sat. $\mathrm{NH}_{4} \mathrm{Cl}(5.0 \mathrm{~mL})$ and extracted with ethyl acetate $(3 \times$ $15 \mathrm{~mL})$. The combined organic extracts were washed with $\mathrm{H}_{2} \mathrm{O}(3 \times 20 \mathrm{~mL})$, dried $\left(\mathrm{Na}_{2} \mathrm{SO}_{4}\right)$, and concentrated under vacuum. The residue was purified by flash column chromatography using ethyl acetate: hexane (9:1) as eluent to provide yellow crystals (5c) $(0.055 \mathrm{~g}, 73 \%)$. ${ }^{1} \mathrm{H}$ NMR $\left(400 \mathrm{MHz}, \mathrm{CDCl}_{3}\right) \delta 7.56(\mathrm{~s}, 1 \mathrm{H}), 7.47-7.43(\mathrm{~m}, 2 \mathrm{H}), 6.99(\mathrm{~s}, 4 \mathrm{H}), 6.62(\mathrm{~s}, 2 \mathrm{H}), 6.60-6.57(\mathrm{~m}$, $2 \mathrm{H}), 4.67(\mathrm{~d}, J=5.6 \mathrm{~Hz}, 2 \mathrm{H}), 4.33-4.28(\mathrm{~m}, 2 \mathrm{H}), 2.36(\mathrm{~s}, 6 \mathrm{H}), 2.15(\mathrm{~s}, 12 \mathrm{H}), 1.34-1.28(\mathrm{~m}$, $7 \mathrm{H}), 0.90-0.85(\mathrm{~m}, 4 \mathrm{H}) .{ }^{13} \mathrm{C}$ NMR $\left(100 \mathrm{MHz}, \mathrm{CDCl}_{3}\right) \delta 167.3,139.0,135.0,133.8,130.2$, 129.4, 127.1, 122.2, 121.0, 117.3, 77.2, 50.4, 35.4, 31.1, 30.2, 26.2, 22.4, 21.1, 17.9, 13.9. HRMS calculated for $\mathrm{C}_{37} \mathrm{H}_{45} \mathrm{~N}_{9} \mathrm{O}[\mathrm{M}+\mathrm{H}]+632.3820$, measured 632.3824 
(E)-4-((1,3-dimesityl-1,3-dihydro-2H-imidazol-2-ylidene)triaz-1-en-1-yl)-N-((1-(3-((7nitrobenzo[c][1,2,5]oxadiazol-4-yl)amino)propyl)-1H-1,2,3-triazol-4-yl)methyl)benzamide $(5 d)$

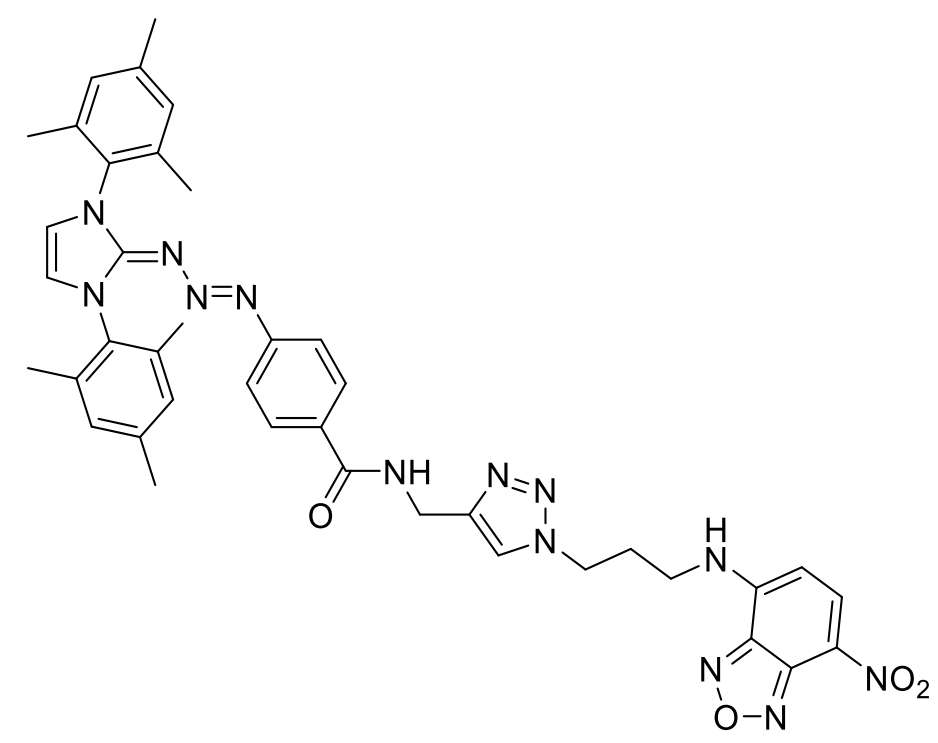

Compound $\mathbf{5 d}$ was synthesized according to a modified literature procedure. ${ }^{5} \mathrm{~A}$ THF solution of $0.15 \mathrm{M}$ of (E)-4-((1,3-dimesityl-1,3-dihydro-2H-imidazol-2-ylidene)triaz-1-en-1-yl)-N-(prop-2-yn1 -yl)benzamide (7) $(0.040 \mathrm{~g}, 0.079 \mathrm{mmol}, 1.0$ equiv.) was added at room temperature, under argon, to a stirred suspension of $\mathrm{N}$-(3-azidopropyl)-7-nitrobenzo[c][1,2,5]-oxadiazol-4-amine ${ }^{7}$ (8) in THF (0.12 mL, $1.0 \mathrm{M}, 0.12 \mathrm{mmol}, 1.5$ equiv.) and Cul $(0.018 \mathrm{~g}, 0.095 \mathrm{mmol}, 1.2$ equiv.), then 1,1,4,7,7-pentamethyldiethylenetriamine $(0.04 \mathrm{~mL}, 0.16 \mathrm{mmol}, 2.0$ equiv.). The mixture was stirred at room temperature for $16 \mathrm{hrs}$. The reaction mixture was loaded onto a basic alumina column to remove the copper catalyst and proceeded to flush with methanol: dichloromethane (1:99) to remove unreacted compounds and followed with methanol: dichloromethane $(5: 95)$ to obtain the product. The mixture was concentrated down under vacuum. The crude mixture was triturated with dichloromethane and hexane. Filtered through a frit funnel and was washed with $200 \mathrm{~mL}$ of ether. The compound proceeded to dry upon vacuum on frit to yield an orange solid (5d) $(0.054 \mathrm{~g}, 89 \%) .{ }^{1} \mathrm{H}$ NMR $\left(400 \mathrm{MHz},\left(\mathrm{CD}_{3}\right)_{2} \mathrm{SO}\right) \delta 9.51(\mathrm{~s}, 1 \mathrm{H}), 8.84(\mathrm{t}, \mathrm{J}=5.8 \mathrm{~Hz}, 1 \mathrm{H}), 8.51$ (d, J = 8.6 Hz, 1H), $7.97(\mathrm{~s}, 1 \mathrm{H}), 7.53(\mathrm{~d}, J=8.6 \mathrm{~Hz}, 2 \mathrm{H}), 7.25(\mathrm{~s}, 2 \mathrm{H}), 7.08(\mathrm{~s}, 4 \mathrm{H}), 6.34(\mathrm{~d}, J=$ $7.7 \mathrm{~Hz}, 3 \mathrm{H}), 4.46(\mathrm{t}, J=6.5 \mathrm{~Hz}, 4 \mathrm{H}), 3.53-3.44(\mathrm{~m}, 2 \mathrm{H}), 2.35(\mathrm{~s}, 6 \mathrm{H}), 2.22(\mathrm{~m}, 2 \mathrm{H}), 2.07(\mathrm{~s}$, $12 \mathrm{H}) .{ }^{13} \mathrm{C}$ NMR $\left(125 \mathrm{MHz},\left(\mathrm{CD}_{3}\right)_{2} \mathrm{SO}\right) \delta 165.7,153.8,150.4,145.3,138.2,137.8,134.4,133.8$, 130., 129.5, 128.8, 127.5, 123.1, 119.8, 118.0, 99.2, 47.0, 40.6, 36.2, 34.8, 28.4, 24.3, 20.7, 17.4, 17.0. HRMS calculated for $\mathrm{C}_{40} \mathrm{H}_{41} \mathrm{~N}_{13} \mathrm{O}_{4}[\mathrm{M}+\mathrm{H}]+768.3477$, measured 768.3473

\section{(E)-4-((2-hydroxy-5-methylphenyl)diazenyl)-N-((1-(4-methoxyphenyl)-1H-1,2,3-triazol-4-} yl)methyl)benzamide (6)<smiles>COc1ccc(-n2cc(CNC(=O)c3ccc(/N=N/c4cc(C)ccc4O)cc3)nn2)cc1</smiles> 
To a solution of (E)-4-((1,3-dimesityl-1,3-dihydro-2H-imidazol-2-ylidene)triaz-1-en-1-yl)-N-((1-(4methoxyphenyl)-1H-1,2,3-triazol-4-yl)methyl)benzamide 5 a $(0.025 \mathrm{~g}, 0.038 \mathrm{mmol}, 1.0$ equiv.) in methanol $(1.6 \mathrm{~mL}), p$-cresol $(0.006 \mathrm{~g}, 0.057 \mathrm{mmol}, 1.5$ equiv.) was added. A $1.2 \mathrm{M}$ solution of formic acid $(0.32 \mathrm{~mL}, 0.38 \mathrm{mmol}, 10.0$ equiv.) was added dropwise to the mixture. The reaction mixture was allowed to stir at room temperature overnight at which an orange solid precipitated out of solution. The solid was collected by using vacuum filtration with a frit funnel and washed with chilled methanol. The solid was than suspended in dichloromethane, washed with sat. $\mathrm{NaHCO}_{3}(5 \mathrm{~mL})$, dried over $\mathrm{Na}_{2} \mathrm{SO}_{4}$ and the solvent was removed under pressure to yield an orange solid (6) $(0.0080 \mathrm{~g}, 47 \%) .{ }^{1} \mathrm{H}$ NMR $\left(500 \mathrm{MHz} \mathrm{CDCl}_{3}\right) \delta 12.57(\mathrm{~s}, 1 \mathrm{H}), 8.03(\mathrm{~s}, 1 \mathrm{H}), 7.99$ - $7.96(\mathrm{~m}, 2 \mathrm{H}), 7.92-7.89(\mathrm{~m}, 2 \mathrm{H}), 7.76(\mathrm{dd}, J=2.2,1.0 \mathrm{~Hz}, 1 \mathrm{H}), 7.65-7.61(\mathrm{~m}, 2 \mathrm{H}), 7.20$ (dd, $J=8.4,2.3 \mathrm{~Hz}, 2 \mathrm{H}), 7.03-7.00(\mathrm{~m}, 2 \mathrm{H}), 6.94(\mathrm{~d}, J=8.4 \mathrm{~Hz}, 1 \mathrm{H}), 4.83(\mathrm{~d}, J=4.9 \mathrm{~Hz}, 2 \mathrm{H})$, $3.86(\mathrm{~s}, 3 \mathrm{H}), 2.39(\mathrm{~s}, 3 \mathrm{H}) .{ }^{13} \mathrm{C}$ NMR $\left(125 \mathrm{MHz}, \mathrm{CDCl}_{3}\right) \delta$ 166.7, 160.1, 152.7, 150.8, 137.4, 135.8, 135.3, 133.4, 130.6, 129.6, 128.5, 122.4, 122.4, 118.1, 115.0, 55.8, 35.6, 20.5. HRMS calculated for $\mathrm{C}_{24} \mathrm{H}_{22} \mathrm{~N}_{6} \mathrm{O}_{3}[\mathrm{M}+\mathrm{Na}]+465.1646$, measured 465.1651

\section{N-((1-(3-((7-nitrobenzo[c][1,2,5]oxadiazol-4-yl)amino)propyl)-1H-1,2,3-triazol-4- yl)methyl)benzamide (7)}

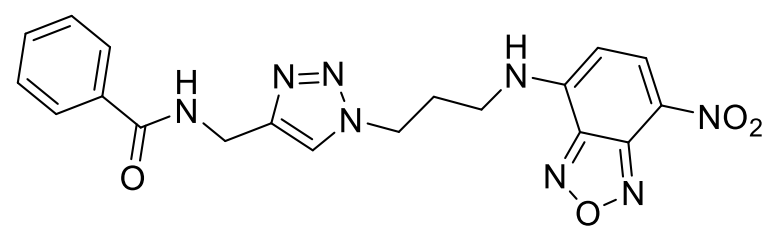

Compound 7 was synthesized according to a modified literature procedure ${ }^{5}$ To a suspension of $\mathrm{N}$-(3-azidopropyl)-7-nitrobenzo[c][1,2,5]-oxadiazol-4-amine ${ }^{7} 8(0.47 \mathrm{~mL}, 1 \mathrm{M}$ in THF, 1.5 equiv.), copper iodide $(0.072 \mathrm{~g}, 0.38 \mathrm{mmol}, 1.15$ equiv.) and 1,1,4,7,7-pentamethyldiethylenetriamine $(0.13 \mathrm{~mL}, 0.62 \mathrm{mmol}, 2.0$ equiv. $)$, in $2.0 \mathrm{~mL}$ THF was added $\mathrm{N}$-(prop-2-yn-1-yl)benzamide ${ }^{8}$ $(0.05 \mathrm{~g}, 0.33 \mathrm{mmol}, 1.0$ equiv.) The mixture was stirred at room temperature for $16 \mathrm{~h}$ and kept under argon. The reaction mixture was quenched by adding a solution of saturated ammonium chloride $(15 \mathrm{~mL})$ and extracted using ethyl acetate $(3 \times 30 \mathrm{~mL})$. The combined organic layers were washed with water $(3 \times 30 \mathrm{~mL})$ and dried using magnesium sulfate and upon the removal of solvent the residue was washed with ether to yield the desired compound as an orange solid $(0.112 \mathrm{~g}, 85) .{ }^{1} \mathrm{H}$ NMR $\left(500 \mathrm{MHz},\left(\mathrm{CD}_{3}\right)_{2} \mathrm{SO}\right) \delta 9.49(\mathrm{~s}, 1 \mathrm{H}), 9.02(\mathrm{t}, \mathrm{J}=5.8 \mathrm{~Hz}, 1 \mathrm{H}), 8.47(\mathrm{~d}, \mathrm{~J}=$ $8.9 \mathrm{~Hz}, 1 \mathrm{H}), 8.02(\mathrm{~s}, 1 \mathrm{H}), 7.89-7.85(\mathrm{~m}, 2 \mathrm{H}), 7.54-7.49(\mathrm{~m}, 1 \mathrm{H}), 7.47-7.41(\mathrm{~m}, 2 \mathrm{H}), 6.32(\mathrm{~d}$, $J=9.0 \mathrm{~Hz}, 1 \mathrm{H}), 4.53-4.44(\mathrm{~m}, 5 \mathrm{H}), 3.48(\mathrm{~s}, 2 \mathrm{H}), 2.24(\mathrm{~h}, \mathrm{~J}=6.7 \mathrm{~Hz}, 2 \mathrm{H}) .{ }^{13} \mathrm{C} \mathrm{NMR}(125 \mathrm{MHz}$, $\left.\left(\mathrm{CD}_{3}\right)_{2} \mathrm{SO}\right) \delta 166.0,145.1,144.4,144.0,137.8,134.0,131.2,128.3,128.2,127.2,123.1,120.9$, 99.1, 47.0, 40.6, 34.9, 28.4. HRMS calculated for $\mathrm{C}_{19} \mathrm{H}_{18} \mathrm{~N}_{8} \mathrm{O}_{4}[\mathrm{M}+\mathrm{Na}]+445.1340$, measured 445.1343 


\title{
Biochemical Procedures
}

\author{
Reduction and Alkylation of Bovine Serum Albumin (BSA)
}

BSA solution (10 $\mu \mathrm{L}$ of $1 \mathrm{mM}$ solution in $1 \mathrm{X}$ PBS) was added to a Eppendorf centrifuge tube. Addition to that were $70 \mu \mathrm{L}$ of $50 \mathrm{mM}$ ammonium bicarbonate in 1X PBS, $10 \mu \mathrm{L}$ of $17 \mathrm{mM} 1,4$ dithiolthreitol (DTT) solution (in $50 \mathrm{mM}$ ammonium bicarbonate) and $10 \mu \mathrm{L}$ of $51 \mathrm{mM}$ iodoacetamide solution (in $50 \mathrm{mM}$ ammonium bicarbonate). The mixture was allowed to incubate at room temp in the dark for $1 \mathrm{hr}$. Acetone $(400 \mu \mathrm{L})$ was added and the mixture was placed in the $-80{ }^{\circ} \mathrm{C}$ freezer for a minimum of $2 \mathrm{hrs}$. Sample removed from freezer, vortex and spun down at $14,000 \mathrm{rpm}$ for $10 \mathrm{~min}$. Supernatant was removed, $100 \mu \mathrm{L}$ of chilled $\left(-80{ }^{\circ} \mathrm{C}\right)$ acetone was added and centrifuged for an additional $5 \mathrm{~min}$. Supernatant was removed and centrifuged for 5 additional min with Eppendorf centrifuge tube cap open to remove residual acetone. Pelleted BSA was suspended in $200 \mu \mathrm{L}$ of $100 \mathrm{mM}$ Tris- $\mathrm{HCl}$ (pH 8.8) (final concentration $50 \mu \mathrm{M} \mathrm{BSA}$ ) and sat on ice for 1 hour before fluorescence labeling experiments.

\section{Control Fluorescent Labeling of BSA with Triazabutadiene 5d, NBD-azide 8, Benzyl-NBD 7}

Compounds 5d, 7 and 8 were each made into $500 \mu \mathrm{M}$ stock solutions in $100 \mathrm{mM}$ Tris-HCl buffer (pH 8.8, 5\% DMSO). $10 \mu \mathrm{L}$ of each compound was removed and added to Eppendorf tube with $25 \mu \mathrm{M}$ Red/Alk-BSA to give them a $100 \mu \mathrm{M}$ concentration. To each reaction vessel, $4 \mu \mathrm{L}$ of $1 \mathrm{M}$ $\mathrm{HCl}$ was added to produce a $\mathrm{pH} \sim 4$ solution (measured by litmus paper) and gave a total volume of $50 \mu \mathrm{L}$. Compound $\mathbf{5 d}$ had two reaction vessels where one was not acidified but stayed at $\mathrm{pH} 8.8$ which acted as an control. After 30 minutes at room temperature, $46.5 \mu \mathrm{L}$ of each reaction was removed and quenched with $2 \mu \mathrm{L}$ of a $250 \mathrm{mM}$ resorcinol solution in $100 \mathrm{mM}$ Tris- $\mathrm{HCl}$ buffer $(\mathrm{pH} 8.8)$, followed by $1.5 \mu \mathrm{L}$ of $6 \% \mathrm{NaOH}$. The quenched samples underwent treatment with Thermo Scientific dye removal columns to remove any excess fluorophore. The protein samples and control were analyzed by SDS-page gel electrophoresis and fluorescent image was detected using a Alexa 488 laser line (Pharos FX Plus Molecular Imager) (Figure 2b).

\section{Fluorescent Labeling of BSA with Triazabutadiene 5d}

$1.2 \mathrm{mg}$ of Triazabutadiene (TBD) $\mathbf{5 d}$ was dissolved in DMSO to produce a $10 \mathrm{mM}$ solution. Followed with the removal of $10 \mu \mathrm{L}$ of the TBD-5d-DMSO solution and added to $190 \mu \mathrm{L}$ of 100 $\mathrm{mM}$ Tris- $\mathrm{HCl}$ buffer ( $\mathrm{pH} 8.8$ ) to produce a $0.5 \mathrm{mM}$ solution (TBD-5d-Tris, $5 \%$ DMSO).

In an $1.5 \mathrm{~mL}$ eppendorf tube, $71 \mu \mathrm{L}$ of $100 \mathrm{mM}$ Tris-HCl buffer $(\mathrm{pH} 8.8)$ and $150 \mu \mathrm{L}$ of Red/AlkBSA $(50 \mu \mathrm{M})$ were added. For the azobenzene formation, $60 \mu \mathrm{L}$ of TBD-5d-Tris $(0.5 \mathrm{mM})$ was added to the eppendorf tube followed by the addition of $19 \mu \mathrm{L}$ of $1 \mathrm{M} \mathrm{HCl}$, which gave the total volume of $300 \mu \mathrm{L}$ and a $\mathrm{pH} \sim 4$ (measurement by $\mathrm{pH}$ paper). Final concentrations were $100 \mu \mathrm{M}$ TBD-5d-Tris and $25 \mu \mathrm{M}$ Red/Alk-BSA. Mixture was incubated at room temp in the dark. At various time points $(0.5,1,5,15$, and $30 \mathrm{~min}), 46.5 \mu \mathrm{L}$ of the mixture was removed and quenched with $2 \mu \mathrm{L}$ of resorcinol $(250 \mathrm{mM})$ in $100 \mathrm{mM}$ Tris-HCl buffer $(\mathrm{pH} 8.8)$ and $1.5 \mu \mathrm{L}$ of $6 \%$ $\mathrm{NaOH}$ ( $\mathrm{pH} \sim 8$, measurement by $\mathrm{pH}$ paper). The quenched samples underwent treatment with Thermo Scientific dye removal columns to remove any excess triazabutadiene. Samples were stored on ice in the dark until analyzed by SDS-page. This continued for remainder of the time points. At the 30 min mark, two $46.5 \mu \mathrm{L}$ aliquots were removed and quenched.

For the negative control, $10 \mu \mathrm{L}$ of TBD-5d-Tris $(0.5 \mathrm{mM})$ was added to $25 \mu \mathrm{L}$ of Red/Alk-BSA $(50 \mu \mathrm{M})$ in $100 \mathrm{mM}$ Tris-HCl buffer $(\mathrm{pH} \mathrm{8.8)}$ and $15 \mu \mathrm{L}$ of $100 \mathrm{mM}$ Tris-HCl buffer (pH 8.8). No 
acidification and after $30 \mathrm{~min}, 2 \mu \mathrm{L}$ of resorcinol $(250 \mathrm{mM})$ in $100 \mathrm{mM}$ Tris-HCl buffer $(\mathrm{pH} 8.8)$ was added. The control also underwent treatment with the Thermo Scientific dye removal column. After all samples went through the Thermo Scientific dye removal column, a Bradford assay was performed to obtain equal loading concentrations for gel electrophoresis. The protein samples and control were analyzed by SDS-page gel electrophoresis and fluorescent image was detected using an Alexa 488 laser line (Pharos FX Plus Molecular Imager). (Figure 2c). 
Triazabutadiene (TBD) $\mathbf{5 d}$ was dissolved in $160 \mu \mathrm{L}$ of DMSO to produce a $10 \mathrm{mM}$ solution. Followed with the removal of $10 \mu \mathrm{L}$ of the TBD-5d-DMSO solution and added to $190 \mu \mathrm{L}$ of 100 $\mathrm{mM}$ Tris- $\mathrm{HCl}$ buffer ( $\mathrm{pH} 8.8$ ) to produce a $0.5 \mathrm{mM}$ stock solution (TBD-5d-Tris). In the aqueous Excitation/Emission spectrum, $100 \mu \mathrm{L}$ of stock TBD-5d-Tris was further diluted with $3 \mathrm{~mL}$ of water for spectroscopy to give a final concentration of $16.6 \mu \mathrm{M}$ of TBD-5d. Excitation and emission of TBD-5d was 471 and $546 \mathrm{~nm}$ and was analyzed using a QuantaMaster 400 Steady State Spectrofluorometer (Figure S1).

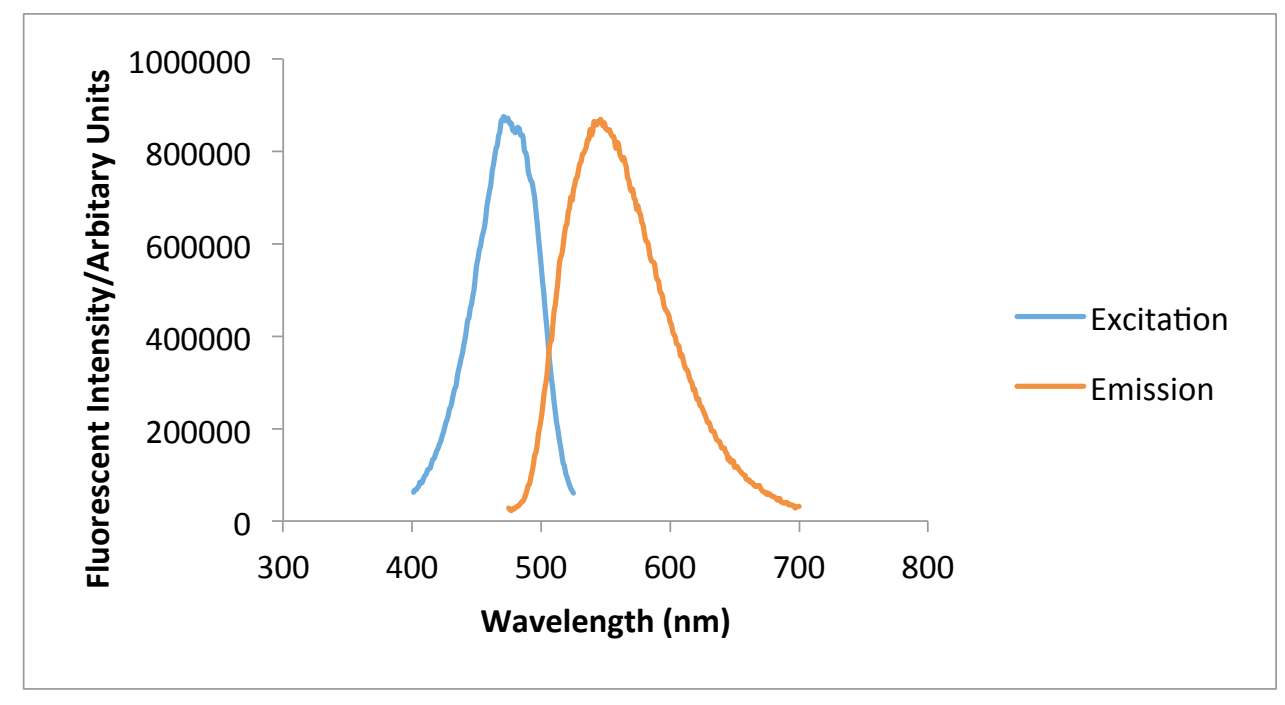

Figure S1. Normalized absorbance and fluorescent emission of triazabutadiene $\mathbf{5 d}$ in aqueous conditions. Excitation= $471 \mathrm{~nm}$. Emission= $546 \mathrm{~nm}$. 


\section{Absorbance and Emission of Triazabutadiene 5d in Dimethyl Sulfoxide}

$1.2 \mathrm{mg}$ of Triazabutadiene (TBD) $\mathbf{5 d}$ was dissolved in $160 \mu \mathrm{L}$ of DMSO to produce a $10 \mathrm{mM}$ solution, which $3.4 \mu \mathrm{L}$ of it was added to $3 \mathrm{~mL}$ of DMSO to produce a final concentration of 0.56 $\mu \mathrm{M}$ TBD-5d. Excitation and emission of TBD-5d was 470 and $534 \mathrm{~nm}$ was analyzed using a QuantaMaster 400 Steady State Spectrofluorometer (FigureS2).

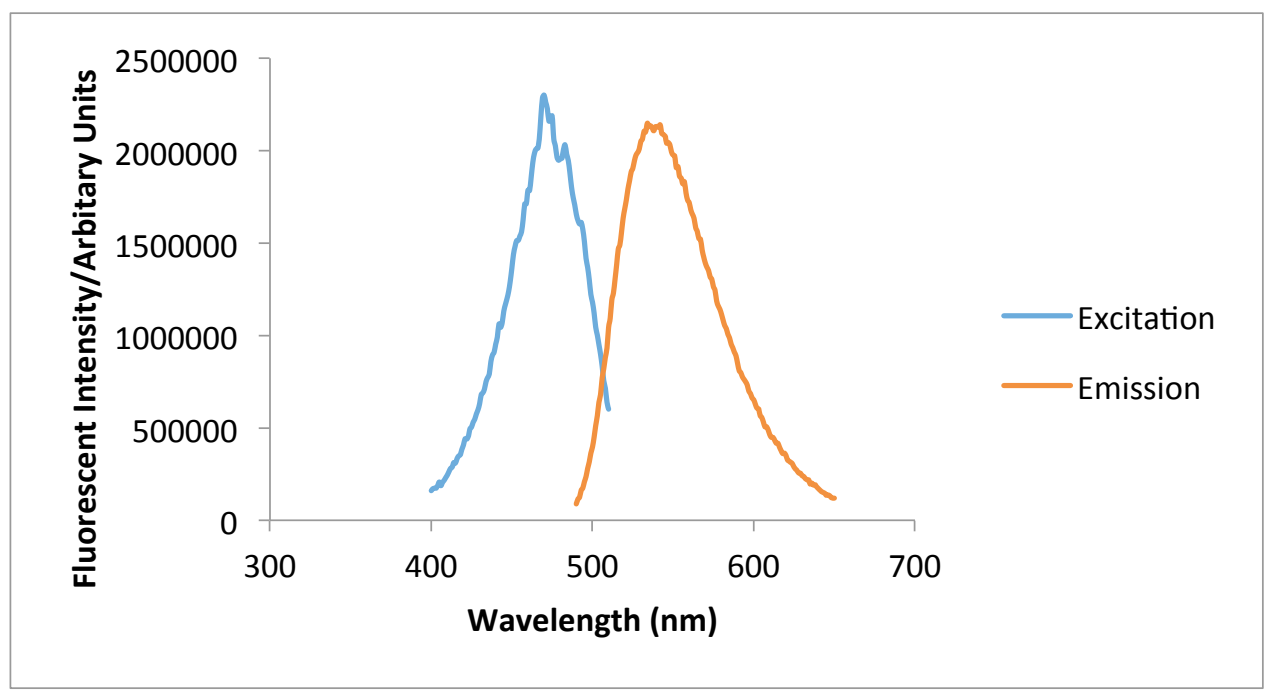

Figure S2. Normalized absorbance and fluorescent emission of triazabutadiene $\mathbf{5 d}$ in DMSO. Excitation $=470 \mathrm{~nm}$. Emission $=534 \mathrm{~nm}$ 


\section{UV/Vis Spectroscopy of Triazabutadiene $5 \boldsymbol{d}$}

TBD-5d was dissolved in DMSO to make a $50 \mu \mathrm{M}$ solution for UV/Vis spectroscopy as shown in Figure S3. UV/Vis absorbance spectra was analyzed using an Agilent 8453 UVvisible Spectrophotometer.

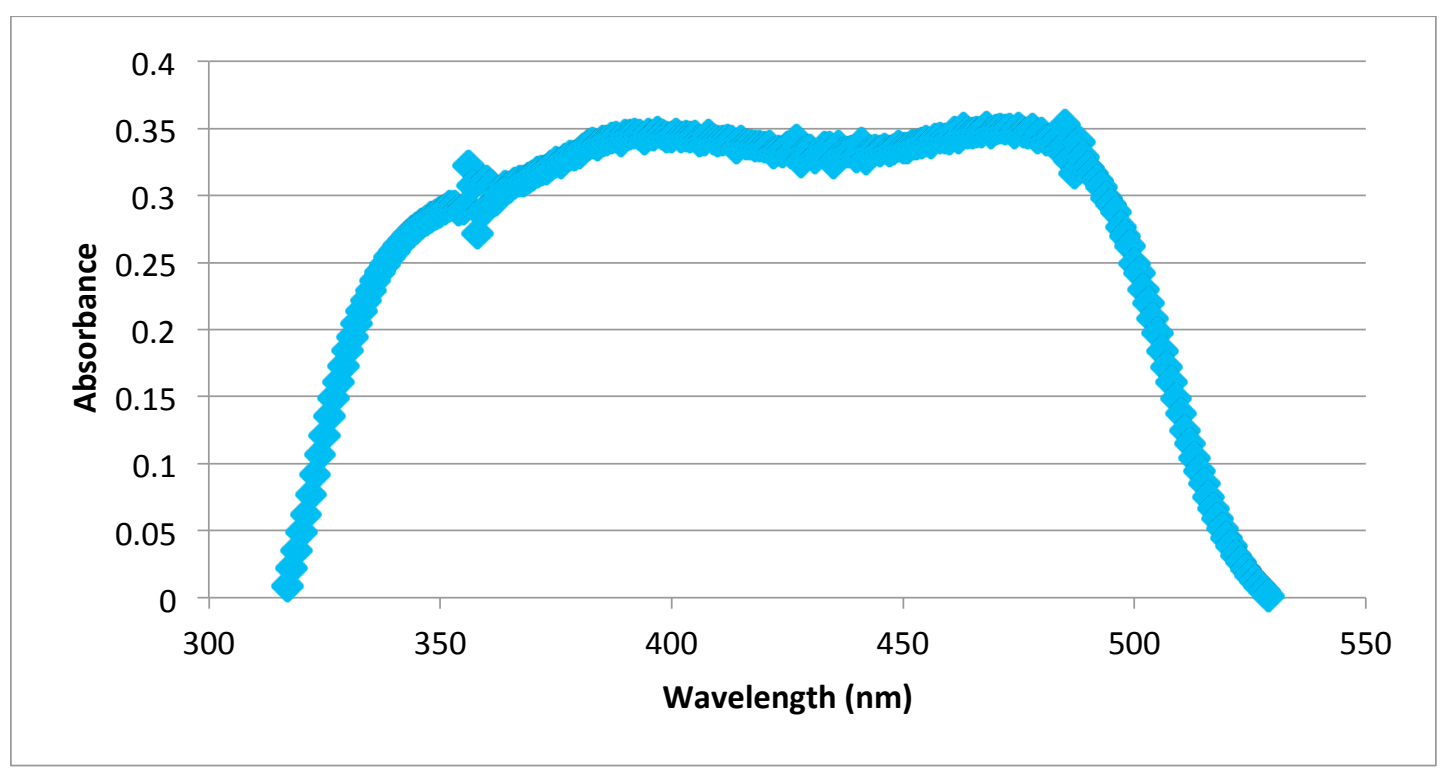

Figure S3. UV/Vis absorbance spectra of triazabutadiene $5 \mathbf{d}(50 \mu \mathrm{M}$ in DMSO)

\section{References}


1. Hahn, F. E.; Langenhahn, V.; Meier, N.; Lügger, T.; Fehlhammer, W. P. Chem. Eur. J. 2003, 9, 3.

2. Patil, S.; White, K.; Bugarin, A. Tetrahedron Lett. 2014, 55, 4826.

3. Hintermann, L. Beilstein J. Org. Chem. 2007, 3, 22.

4. Jiang, C.-s..; Wang, X-.m.; Zhang, S.-q.; Meng, L.-s.; Zhu, W.-h.; Jing, X.; Lu, S.-m. Bioorg. Med. Chem. 2015, 23, 6510.

5. Fiandanese, V.; Bottalico, D.; Marchese, G.; Punzi, A.; Quarta, M. R.; Fittipaldi, M. Synthesis 2009, 22, 3853.

6. Zhang, Q.; Shrestha, J. P.; Chang, C. T. Tetrahedron Lett. 2014, 55, 1839.

7. Key, J. A.; Cairo, C. W. Dyes and Pigments 2011, 88, 95.

8. Wipf, P.; Aoyama, Y.; Benedum, T. E. Org. Lett. 2004, 6, 3593. 